\title{
BANKS, GROWTH AND GEOGRAPHY
}

\section{Raju Jan Singh}

No. 127

May 1997

The author thanks Ben Bernanke and Barbara Schlaffer as well as an anonymous referee for their helpful suggestions.

UNCTAD/OSG/DP.127 
The opinions expressed in this paper are those of the author and do not necessarily reflect the views of UNCTAD. The designations and terminology employed are also those of the author.

UNCTAD Discussion Papers are read anonymously by at least one referee, whose comments are taken into account before publication.

Comments on this paper are invited and should be addressed to the author, c/o Editorial Assistant, Editorial Board, United Nations Conference on Trade and Development (UNCTAD), Palais des Nations, 1211 Geneva 10, Switzerland. Copies of the UNCTAD Review, Discussion Papers and Reprint Series may also be obtained from this address (Tel. No. 022-907.5733; Fax No. 907.0043). 


\section{CONTENTS}

Chapter

Page

I. MODEL WITHOUT FINANCIAL INTERMEDIATION 2
A. The environment
2
B. Factor markets
C. Goods market
D. Steady states

II. MODEL WITH FINANCIAL INTERMEDIATION 7
A. Portfolio diversification
B. Asset valuation
7
C. Steady states

III. GROWTH AND THE STRUCTURE OF THE FINANCIAL SECTOR 10

IV. CONCLUSIONS 11

MATHEMATICAL APPENDIX 13

REFERENCES 18 


\title{
BANKS, GROWTH AND GEOGRAPHY
}

\author{
Raju Jan Singh
}

Swiss Federal Administration of Finance, Berne

\begin{abstract}
This paper presents a general equilibrium endogenous growth model, in which financial intermediaries evaluate the quality of projects, mobilize savings to finance the most promising ones and diversify risk. Information technology available to banks is linked to geographic proximity. This valuation capacity increases the proportion of high-return projects being financed, and thereby accelerates economic growth. This positive effect does not depend on the degree of individuals' risk aversion.
\end{abstract}

\section{INTRODUCTION}

The importance of financial markets in fostering economic growth has long been stressed by economists. Early contributions by Goldsmith (1969), McKinnon (1973) and Shaw (1973) mentioned the empirical correlation between financial and economic development. They argued that financial intermediation promoted growth through greater accumulation of capital, improved mobilization of savings and enhanced efficiency in resource allocation. Theoretically, however, links between financial intermediation and growth were difficult to formalize. In traditional growth theory, financial development could only have an influence on the level of economic activity, but not on its long-run growth rate.

The development of endogenous growth models, which show that growth rates can be related to institutional arrangements, has made it possible to formalize the presentation of the interactions between financial markets and economic growth. In these models, financial intermediation fosters economic growth basically in two ways. First, by providing an opportunity to hold a diversified portfolio, a financial intermediary enables risk-averse individuals to invest in riskier but more productive assets or technologies (see, for instance, Bencivenga and Smith, 1991; Levine, 1991; Saint-Paul, 1992). Second, by gathering information, a financial intermediary is able to improve the quality of projects being financed (Greenwood and Jovanovic, 1990; King and Levine, 1993b). In this last group of models, the information technology available to financial intermediaries is assumed to be given.

It has been claimed that banks are able to gather this additional information at a lower cost than other financial intermediaries, through the process of taking deposits and through close contacts with customers (Fama, 1985). Frequent contacts with potential borrowers provide banks with a better knowledge of their clients and help them to evaluate less tangible but nevertheless important "assets", such as managerial skills or dynamism.

This view that a link could exist between proximity and more efficient lending has been pointed out by historians. Cameron (1967) in his study on banking in the early stages of industrialization stressed that 
proximity enabled banks to better identify the potentialities of local communities. In order to use personal contact and detailed knowledge of local conditions, he mentioned for instance that the successful Scottish bankers of the 18th and 19th centuries used to hire businessmen of the communities in which they located branches. He suggested furthermore that the slow progress of industrialization in France during the 19th century could be linked to the underdevelopment of its banking system, characterized, among other things, by one of the lowest banking densities of any developed country.

The existence of such a link is also confirmed by more recent empirical studies. Jayaratne and Strahan (1996), for instance, studied the growth effects of the relaxation of bank branch restrictions in the United States. They show that improvements in the quality of bank-lending, not increased volume of bank-lending, has been responsible for the faster growth experienced after deregulation.

Based on these empirical observations, this paper presents a model explicitly linking the information technology available to banks to geographic proximity and thereby introduces the notion of geography into the interaction of financial intermediation and growth. The paper will proceed as follows. A model without financial intermediaries will be discussed first in chapter I. Chapter II will introduce financial intermediation in the form of banks, modelled as institutions providing both portfolio diversification and asset valuation, and discuss its effects on growth. Finally, chapter III will provide some insights into the influence of financial intermediation on economic growth when taking geography into account. Following Cameron (1967), McKinnon (1973) and Shaw (1973), the stage of development of the financial sector will be assumed to be exogenous ${ }^{1}$.

\section{MODEL WITHOUT FINANCIAL INTERMEDIATION}

\section{A. The environment}

The economy is described by a simple overlapping generations model. As its name suggests, the structure of this model allows at any one time individuals of different generations to coexist and trade with one another. The aggregate implications of life-cycle savings by individuals can therefore be easily and explicitly studied. Another feature that makes this model attractive is that it is entirely built from microeconomic fundamentals. The preferences of individuals, the resources they have and the technology they can use are all explicitly taken into account, allowing one to derive endogenously important variables such as the rate of savings or capital accumulation.

These authors argued that differences in the development of financial markets across countries depended primarily on government regulation. 
As with all recent models dealing with growth, the overlapping generations model is set in a general equilibrium framework. Individuals own the inputs of the economy and choose the fractions of their income to consume and save. Firms hire inputs and use them to produce goods that they then sell to individuals. Finally, markets exist on which firms exchange their goods and individuals sell their inputs. The quantities demanded and supplied determine the relative price of inputs and produced goods. As such models tend to become quickly complicated, simplifications are necessary. In order to focus here on financial intermediation and on its contribution to real growth, a real economy will be considered. There will be, therefore, no money and all exchanges will be barter ones.

Within this general structure, the model used here has the following characteristics. Each generation lives two periods and is composed of risk-averse individuals. The number of individuals born at any time is constant and is normalized to one. An individual $h$ born at time $t$ consumes $c_{t}^{h}(t)$ during period $t$ and $c_{t}^{h}(t+1)$ in period $t+1$ and has a utility function of the form:

$$
U\left(c_{t}{ }^{h}\right)=\sum_{i=1}^{2} \ln c_{t}^{h}(i)
$$

Individuals work only when young, supplying inelastically one unit of labour and earning a real wage of $w_{t}^{h}(t)$. When they are old, they become entrepreneurs. Therefore they consume only part of their first-period income and save the rest to finance their second-period business and consumption.

There is only one good that can be either consumed or invested, and which is produced by the older generation by combining the capital stock it has saved with labour supplied by the young. In order to start production, however, entrepreneurs need to finance a project. Entrepreneurs have to choose from a pool composed of two types of projects. A proportion $\pi$ are high-return projects and yield a positive return $F$. The remaining $(1-\pi)$ provide zero returns. Of course, all individuals would prefer a high-return project, but unfortunately they cannot distinguish them ex ante. The production process is therefore stochastic, and may be described by the following production function for each firm:

$$
\begin{aligned}
& \widetilde{F}\left(\underline{k}_{t-1}, k_{t-1}, L_{t}\right)=\Theta \underline{k}_{t-1}{ }^{\beta} k_{t-1}{ }^{\alpha} L_{t}{ }^{1-\alpha} \\
& \Theta=\left\{\begin{array}{lll}
1 & \text { probability } & \pi \\
0 & \text { probability } & 1-\pi
\end{array}\right.
\end{aligned}
$$

$k_{t-1}$ is the capital stock per firm, saved by generation $t-1$, and $\mathrm{L}_{\mathrm{t}}$ is the labour force employed by an entrepreneur. $\underline{k}_{t-1}$ is the average capital stock per firm at date $t$ and represents a technological spillover in the 
spirit of Romer (1986). From an individual's viewpoint, $\underline{k}_{t-1}$ is given and the production function he faces has the traditional characteristics of decreasing returns to scale. For the economy as a whole, however, the returns to accumulate capital do not diminish. For simplicity, it is assumed that the capital stock depreciates completely during one period.

\section{B. Factor markets}

The labour market is competitive. Labour will thus be priced at its marginal productivity. However, entrepreneurs whose projects fail do not pay wages. As workers may be employed by one entrepreneur only, individual wage income will be stochastic. Following van Ees and van den Heuvel (1994), a perfect insurance market will be assumed, where individuals can find full insurance against this individual labour income risk. With full labour income insurance, individual labour income becomes certain and equal to expected labour income:

$$
E\left(\widetilde{w}_{t}^{h}(t)\right)=(1-\alpha) \pi \underline{k}_{t-1} L_{t}^{-\alpha}=\bar{w}_{t}^{h}(t)
$$

where $(1-\alpha) \underline{k}_{t-1} L_{t}^{-\alpha}$ is the marginal productivity of labour and $\pi$ is the probability for the entrepreneur to have chosen a high-return project, and thus for his workers to be paid.

In the absence of a rental market for capital, entrepreneurs use only their own capital in production. As production is stochastic, the return on capital will be uncertain too. Subtracting the wage bill from the firm's output and dividing by the stock of capital yields, the following return on capital:

$$
\tilde{r}_{t}(t+1)=\left\{\begin{array}{lll}
\alpha \underline{k}_{t}{ }^{\beta} k_{t}{ }^{\alpha-1} L_{t+1}{ }^{1-\alpha} & \text { probability } & \pi \\
0 & \text { probability } 1-\pi
\end{array}\right.
$$

which amounts to the marginal productivity of capital.

\section{Goods market}

The goods market equilibrium requires that the demand for goods in each period be equal to the supply, or equivalently that investment be equal to savings:

$$
S_{t}(t)=K_{t}(t+1)
$$

where $S_{t}(t)$ denotes savings and $K_{t}(t+1)$ the investment made by generation $t$, yielding a return in period $t+1$.

Taking the average yields:

$$
s_{t}{ }^{h}(t)=\underline{k}_{t}(t+1)
$$




\section{Steady states}

As individuals do not know the quality of the project they are financing, their second period income and, therefore consumption, is stochastic:

$$
\widetilde{c}_{t}^{h}(t+1)=\widetilde{r}_{t}(t+1) k_{t}^{h}(t+1)=\left\{\begin{array}{lll}
r_{t}(t+1) k_{t}^{h}(t+1) & \text { probability } & \pi \\
0 & \text { probability } & 1-\pi
\end{array}\right.
$$

where $r_{t}(t+1)=\alpha \underline{k}_{t}^{\beta} k_{t}^{\alpha-1} L_{t+1}^{1-\alpha}$.

Their second period utility function will therefore also be stochastic :

$$
\ln \widetilde{c}_{t}^{h}(t+1)=\left\{\begin{array}{lll}
\ln \left[r_{t}(t+1) k_{t}^{h}(t+1)\right] & \text { probability } \pi \\
0 & \text { probability } 1-\pi
\end{array}\right.
$$

An individual $h$ in period $t$ will thus maximize an expected utility function of the following form :

$$
\operatorname{MaxEU}\left(c_{t}{ }^{h}\right)=\ln c_{t}{ }^{h}(t)+\pi \ln c_{t}{ }^{h}(t+1)
$$

under his intertemporal budget constraint :

$$
c_{t}{ }^{h}(t)+\frac{c_{t}{ }^{h}(t+1)}{r_{t}(t+1)}=\bar{w}_{t}{ }^{h}(t)
$$

where his wage earned in period $t$ is equal to his consumption in period $t$ and the discounted consumption in period $t+1$.

Solving this problem yields the following time paths for consumption and savings (a detailed solution is presented in the mathematical appendix) :

$$
\begin{aligned}
& c_{t}{ }^{h}(t)=\frac{\bar{w}_{t}{ }^{h}(t)}{1+\pi} \\
& s_{t}{ }^{h}(t)=\bar{w}_{t}{ }^{h}(t)\left(\frac{\pi}{1+\pi}\right)
\end{aligned}
$$

The long-run growth rate of this economy is determined by the evolution of the technological spillover factor, $\underline{k}_{t}$. The growth rate of this variable is obtained using (3), (6) and (12):

$$
\frac{\underline{k}_{t}(t+1)}{\underline{k}_{t-1}(t)}=\frac{(1-\alpha) \pi^{2} L_{t}^{-\alpha}}{1+\pi}=\mu
$$

Differentiating partially $\mu$ with respect to $\pi$ yields :

$$
\frac{\partial \mu}{\partial \pi}=\frac{\pi(1-\alpha) L_{t}^{-\alpha}(2+\pi)}{(1+\pi)^{2}}>0
$$

The long-run growth rate of this economy will thus depend positively on the proportion $\pi$ of high-return projects being undertaken. 


\section{MODEL WITH FINANCIAL INTERMEDIATION}

\section{A. Portfolio diversification}

Let us now assume the existence of banks. This allows us to dissociate the savings activity from the investment decision. An entrepreneur will not need to use his own capital to set up his business, but will be able to borrow the needed amount from a bank. If his project succeeds, he will earn a return $r_{t}(t+1)$ per unit of capital invested minus the servicing of his loan, $i_{t}(t+1)$. If the project fails, he will not have enough resources to pay off his debt and will be forced to declare bankruptcy. An entrepreneur $h$ born at time $t$ will therefore have an expected pay-off function, $v_{t}^{h}(t+1)$, of the following form:

$$
v_{t}^{h}(t+1)=\pi k_{t}^{h}(t+1)\left[r_{t}(t+1)-i_{t}(t+1)\right]
$$

To attract the savings of individuals, banks offer deposits yielding a return $d_{t}(t+1)$. By granting loans to a number of entrepreneurs, they are able to diversify individual risk away. The return on deposits therefore becomes certain, as well as individuals' second-period income and consumption:

$$
c_{t}{ }^{h}(t+1)=d_{t}(t+1) s_{t}{ }^{h}(t)
$$

Second-period consumption being fixed, the utility function of individuals and the intertemporal budget constraint become:

$$
\begin{aligned}
& U\left(c_{t}{ }^{h}\right)=\ln c_{t}{ }^{h}(t)+\ln c_{t}{ }^{h}(t+1) \\
& c_{t}{ }^{h}(t)+\frac{c_{t}{ }^{h}(t+1)}{d_{t}(t+1)}=\bar{w}_{t}{ }^{h}(t)
\end{aligned}
$$

\section{B. Asset valuation}

If banks were only offering a diversification facility, they could be replaced by an insurance company. Here, the specificity of banks is that, in addition to offering a diversified portfolio, a bank also performs the function of asset valuation. This evaluation, however, is costly and will be a function of the distance between the entrepreneur and the bank. The further away the entrepreneur, the higher this cost will be.

Entrepreneurs will be assumed to be uniformally distributed along $\delta 0[0,1] \delta$ being the distance between a bank branch, or the credit department, and its client. By paying a cost $\kappa$ per unit of $\delta^{2} \kappa>0$, a bank will gather information enabling it to evaluate the true quality of the project that an entrepreneur is facing. Let us assume that in this case, with the help of the bank, the entrepreneur will always be able to choose a high-return project. However, as this activity is costly, the bank will not evaluate all its potential borrowers, but only a proportion $\delta^{*}$ of them. At this point, the improvement in the performance of its loan portfolio achieved by gathering information will equal the cost of collecting this information. 
If an entrepreneur succeeds, the lender receives the interest on the loan and the principal, $i_{t}(t+1)$. If the project fails and the borrower defaults, the bank looses its claim. The bank's profit function, $\rho_{t}(t+1)$, on loans granted at period $t$ may thus be written as:

$$
\rho_{t}(t+1) K_{t}(t+1)=\left[\delta^{*}+\left(1-\delta^{*}\right) \pi\right] i_{t}(t+1) K_{t}(t+1)-d_{t}(t+1) S_{t}(t)-\kappa \delta^{* 2}
$$

where $\left(\delta^{*}+\left(1-\delta^{*}\right) \pi\right)$ is the proportion of high-return projects being financed by the bank and

$$
\delta^{*}=\frac{(1-\pi) i_{t}(t+1) K_{t}(t+1)}{\kappa}
$$

The share of projects being evaluated, $\delta^{*}$, is thus positively related to the proportion of zero return projects in the pool, $(1-\pi)$, to the interest rate the bank charges on its loans, $i_{t}(t+1)$, and to the amount of these loans, $K_{t}(t+1)$. By contrast, the cost of gathering information, $\kappa$, will influence this share negatively (for a derivation of equation 20 , please refer to the mathematical appendix).

\section{Steady states}

Following Bencivenga and Smith (1991), the bank is viewed here as a cooperative entity, maximizing its depositors' utility under its own and the entrepreneurs' zero profit constraints given by equations (15) and (19). As previously noted, the proportion of projects being evaluated, $\delta^{*}$, will increase as the amount lent by the bank increases. This process will take place until $\delta^{*}$ reaches the value of one. In the steady state, therefore, all the projects will be evaluated.

The solutions for the time paths for consumption and savings, for the long-run growth rate and for the deposit and lending rates are presented in table 1. For the sake of comparison, the solutions for the case where the bank would only provide a diversification facility are also presented.

Table 1

\begin{tabular}{l|c|c}
\hline & $\begin{array}{c}\text { Portfolio diversification } \\
\text { without asset valuation }\end{array}$ & $\begin{array}{c}\text { Portfolio diversification } \\
\text { and asset valuation }\end{array}$ \\
\hline $\mathrm{c}_{\mathrm{t}}^{\mathrm{h}}(\mathrm{t})$ & $\frac{\bar{w}_{t}{ }^{h}(t)}{2}$ & $\frac{\bar{w}_{t}{ }^{h}(t)}{2}$
\end{tabular}




\begin{tabular}{c|c|c}
$s_{t}{ }^{h}(t)$ & $\frac{\bar{w}_{t}{ }^{h}(t)}{2}$ & $\frac{\bar{w}_{t}{ }^{h}(t)}{2}$ \\
$\frac{k_{t}(t+1),}{\underline{k}_{t-1}(t)}$ & $\frac{(1-\alpha) \pi L_{t}^{-\alpha}}{2}$ & $\frac{(1-\alpha) L_{t}^{-\alpha}}{2}$ \\
$d_{t}(t+1)$ & $\pi i_{t}(t+1)$ & $i_{t}(t+1)-\frac{\kappa}{K_{t}(t+1)}$ \\
$\mathrm{i}_{\mathrm{t}}(\mathrm{t}+1)$ & $\mathrm{r}_{\mathrm{t}}(\mathrm{t}+1)$ & $\mathrm{r}_{\mathrm{t}}(\mathrm{t}+1)$ \\
\hline
\end{tabular}

Comparing first of all the steady states in the absence of financial intermediation to those where banks would only provide the economy with a diversified portfolio, one notices that the deposit rate an individual receives on his bank account is identical to the expected rate of return expressed in equation (4). But while equation (4) describes a random variable, the deposit rate is fixed. As individuals are assumed here to be risk averse, they will always prefer receiving this fixed rate of interest on their deposit account to a random rate of return on their projects. In this model, they will therefore always prefer to deposit their savings in a bank account and to borrow the needed capital for their project rather than to self-finance it.

This sure return on savings leads to an increase in the savings rate and promotes faster growth, as it can be seen by subtracting the savings rate in the absence of financial intermediation, given by equation (12), from the expression in table 1. As Pagano (1993) points out, this result stems from the utility function assumed in this paper.

The effects of risk diversification on savings and growth rates are generally ambiguous. On the one hand, risk diversification allows a secure return on savings. The incentive for postponing consumption is thus increased. On the other hand, reduced risk also implies a reduced need for precautionary savings. Risk diversification therefore leads to an ambiguous response of savings. This response is negative for utility functions with a constant coefficient of relative risk aversion higher than one, and positive otherwise. By assuming a logarithmic utility function in this paper, the risk-aversion coefficient was set to one.

Asset valuation, by contrast, does not result in any influence on the savings rate. This activity influences the growth rate by increasing the proportion of high-return projects being financed. In the steady state all projects undertaken are high-return ones. This evaluation leads to a more efficient resource allocation and to a faster growth rate. Unlike risk-sharing, the growth effect of asset valuation is not ambiguous and does not depend on the individuals' risk-aversion.

As shown by the solutions for deposit rates, the cost of undertaking evaluations is covered by the spread between the lending rate net of defaults and the deposit rate. As long as $\delta^{*} \leq 1$, the deposit rate offered by a bank providing only risk diversification is identical to the rate it would offer if it undertook in addition asset valuation. Information costs are entirely covered by improvements in the performance of the loan portfolio. Once all projects are being evaluated, however, the relative cost of this activity decreases as 
the amount of capital lent to the economy increases. As this amount grows, the spread between the deposit rate and the lending rate will narrow.

\section{GROWTH AND THE STRUCTURE OF THE FINANCIAL SECTOR}

The previous section showed that in the steady state, by evaluating all the projects being financed, the bank is able to improve the efficiency of its lending. Inefficiencies remain, however, in the transition to this steady state, since during this phase the amount of capital lent to the economy would not be enough to induce the bank to evaluate all the projects. In this case, the model presented in this paper assumes that the bank should also deal with the $\left(1-\delta^{*}\right)$ borrowers whose projects could not be evaluated.

Further improvement could be achieved in the quality of lending if the bank could open branches further away to deal with these borrowers. In total, $1 / \delta^{*}$ bank branches could operate, each catering for only a proportion $\delta^{*}$ of entrepreneurs. In this case, all their lending would be used to finance high-return projects and the optimal resource allocation would be achieved. Government regulations placing constraints on bank branches and therefore forcing banks to operate beyond their $\delta^{*}$ threshold would depress growth. As observed by Jayaratne and Strahan (1996), relaxing such rules would lead to more efficient bank-lending and faster growth.

This observation implies that the structure of the financial sector matters. Risk-sharing requires pooling large amounts of savings and spreading lending across a number of projects and depends mainly on the size of the financial sector. Asset valuation, by contrast, requires proximity. An expansion of the financial sector led by large banks, present in the capital city but with only few branches in the country, while improving risk diversification would have little influence on the efficiency of lending. By contrast, the development of a large number of unit banks could have a beneficial effect on efficiency, but would end up with poorly diversified loan portfolios if risks were not uniformly distributed across the country. Large banks with a wide network of branches endowed with some autonomy in their lending decisions could represent some intermediate solution, combining both the ability to share risk and to collect information.

In addition, taking geography into account while discussing the influence of finance on economic growth implies that not only the overall amount of mobilized savings matters, but also its distribution within the financial sector. The model presented in this paper would suggest that the contribution to growth of this sector will be different, according to whether deposits are fairly spread across the country or heavily concentrated in banks having few branches or contacts outside the capital city. Similarly, the shifts in this distribution from banks with wide branch networks to banks only present in some big cities would imply a negative effect on economic growth, even if the total amount of savings mobilized remains unchanged. 


\section{CONCLUSIONS}

Recent developments in growth theory have stimulated renewed interest in the interactions of financial intermediation and growth. While most of the existing literature analyses the risk- sharing function of financial intermediaries, this paper focuses on the asset-valuation activity of banks. Following the early contributions of Goldsmith (1969), McKinnon (1973) and Shaw (1973), a general equilibrium endogenous growth model is presented here in which financial intermediaries increase the amount of accumulated capital, improve the mobilization of savings and enhance the efficiency of resource allocation.

As in Greenwood and Jovanovic (1990) and King and Levine (1993b), banks are shown to be able to improve their lending efficiency by evaluating projects. Unlike the models presented by these authors, the banks' evaluation capacity is not assumed to be exogenous. The ability of banks to gather the information needed to undertake this evaluation is linked here to proximity, and the notion of geography may thereby be introduced. A link between proximity and faster growth rates can thus be shown, consistent with the observations of historians such as Cameron (1967).

Furthermore, this paper shows that a bank can improve the efficiency of its lending by opening branches. A poor branch network would thus affect negatively the economic growth rate, as Cameron (1967) suggests in the case of France in the 19th century. By contrast, relaxing regulations limiting the setting up of branches would promote faster growth, as Jayaratne and Strahan (1996) observe in the case of the United States. The size of the financial sector is therefore not the only important variable; its structure and the distribution of its deposits matter likewise.

Finally, the model also shows that the positive effect of asset valuation on economic growth does not require any constraint on the utility function of individuals. The positive effect is unambiguous. This result stands in contrast to that obtained when limiting the role of banks to risk diversification. In the latter case, the effect of financial development on growth is ambiguous, depending on the degree of the risk aversion of individuals.

The model presented in this paper could be extended in various ways. The contract offered by the bank to its potential borrowers could be enriched by the inclusion of other variables besides the interest rate. For instance, collateral requirements might be considered. Cash-flow or corporate net wealth could also be introduced as additional sources of information for banks. In this context, the proportion of entrepreneurs being evaluated might appear to be dependent on the size of the latter only, and not only on the proximity of a bank branch. Another possible extension could be to set the analysis within a business-cycle framework.

Recent literature linking capital market imperfections to macroeconomic models has emphasized the role the financial sector can play in triggering or deepening economic crises. Runs or adverse shocks affecting corporate cash flow or net worth (Bernanke and Gertler, 1989) have attracted considerable interest. Extending the model presented here would suggest that, by increasing the proportion of borrowers whose projects will not be evaluated, restructuring and bank branch closures taking place in the aftermath of a recession may reduce lending efficiency, deepen the downturn, and thus exacerbate economic fluctuations. 
Finally, greater attention could be paid in empirical studies to the structure of the financial sector. Following King and Levine (1993a and 1993b), investigations of the factors explaining international differences in long-run growth rates could probably gain by not only considering the size of the banking sector, but also proxies for the quality of its lending. In this respect, cross-country discrepancies in bank density, for instance, could be an interesting variable to examine.

This paper has, however, only looked at corporate lending, and its conclusions should be interpreted within these limits. The effects of financial development in other markets may be significantly different. Improved conditions for household credit, for instance, may reduce the need to save first in order to purchase durable goods, and would therefore lead to lower savings and associated lower growth rates. Not all forms of financial developments are necessarily conducive to faster growth. 


\section{MATHEMATICAL APPENDIX}

\section{Steady states without financial intermediation}

Problem :

$\operatorname{Max} U=\ln c_{t}{ }^{h}(t)+\pi \ln c_{t}{ }^{h}(t+1)$

s.t.

$$
c_{t}^{h}(t)+\frac{c_{t}{ }^{h}(t+1)}{r_{t}(t+1)}=\bar{w}_{t}^{h}(t)
$$

The Lagrangian is therefore :

$$
L=\ln c_{t}{ }^{h}(t)+\pi \ln c_{t}{ }^{h}(t+1)+\lambda\left[c_{t}{ }^{h}(t)+\frac{c_{t}{ }^{h}(t+1)}{r_{t}(t+1)}-\bar{w}_{t}{ }^{h}(t)\right]
$$

and the first order conditions are :

$$
\begin{gathered}
\frac{\partial L}{\partial c_{t}{ }^{h}(t)}=\frac{1}{c_{t}{ }^{h}(t)}=-\lambda \\
\frac{\partial L}{\partial c_{t}{ }^{h}(t+1)}=\frac{\pi}{c_{t}{ }^{h}(t+1)}=-\frac{\lambda}{r_{t}(t+1)} \\
\Rightarrow \quad-\lambda=\frac{\pi r_{t}(t+1)}{c_{t}{ }^{h}(t+1)} \\
\frac{\partial L}{\partial \lambda}=c_{t}{ }^{h}(t)+\frac{c_{t}{ }^{h}(t+1)}{r_{t}(t+1)}-\bar{w}_{t}{ }^{h}(t)=0
\end{gathered}
$$

Equating (A1) and (A2) yields :

$$
\begin{aligned}
& \frac{1}{c_{t}{ }^{h}(t)}=\frac{\pi r_{t}(t+1)}{c_{t}{ }^{h}(t+1)} \\
& \frac{c_{t}{ }^{h}(t+1)}{\pi c^{h}(t)}=r_{t}(t+1)
\end{aligned}
$$


From (A3), :

$$
c_{t}^{h}(t+1)=\left[\bar{w}_{t}^{h}(t)-c_{t}^{h}(t)\right] r_{t}(t+1)
$$

Substituting (A5) into (A4) yields :

$$
\begin{array}{rlrl} 
& & {\left[\bar{w}_{t}{ }^{h}(t)-c_{t}{ }^{h}(t)\right]=\pi c_{t}{ }^{h}(t)} \\
\Rightarrow \quad & \bar{w}_{t}{ }^{h}(t)=(1+\pi) c_{t}{ }^{h}(t) \\
\Rightarrow \quad & c_{t}{ }^{h}(t)=\frac{\bar{w}_{t}{ }^{h}(t)}{1+\pi}
\end{array}
$$

To obtain savings, one subtracts consumption from income :

$$
\begin{aligned}
s_{t}{ }^{h}(t) & =\bar{w}_{t}{ }^{h}(t)-c_{t}{ }^{h}(t) \\
\Rightarrow \quad s_{t}{ }^{h}(t) & =\bar{w}_{t}{ }^{h}(t)-\frac{\bar{w}_{t}{ }^{h}(t)}{(1+\pi)} \\
\Rightarrow \quad s_{t}{ }^{h}(t) & =\bar{w}_{t}{ }^{h}(t)\left(\frac{\pi}{1+\pi}\right)
\end{aligned}
$$

The growth rate of $\underline{k}_{t}$ is obtained with the following equations :

$$
\begin{aligned}
& \bar{w}_{t}{ }^{h}(t)=(1-\alpha) \pi \underline{k}_{t-1}(t) L_{t}{ }^{-\alpha} \\
& s_{t}{ }^{h}(t)=\underline{k}_{t}(t+1) \\
& s_{t}{ }^{h}(t)=\bar{w}_{t}{ }^{h}(t)\left(\frac{\pi}{1+\pi}\right)
\end{aligned}
$$

Substituting (A6) into (A8) yields :

$$
s_{t}^{h}(t)=(1-\alpha) \pi \underline{k}_{t-1}(t) L_{t}^{-\alpha}\left(\frac{\pi}{1+\pi}\right)
$$

Using (A7) :

$$
\begin{aligned}
\underline{k}_{t}(t+1) & =(1-\alpha) \pi \underline{k}_{t-1}(t) L_{t}^{-\alpha}\left(\frac{\pi}{1+\pi}\right) \\
\Rightarrow \quad & \frac{\underline{k}_{t}(t+1)}{\underline{k}_{t-1}(t)}=\frac{(1-\alpha) \pi^{2} L_{t}^{-\alpha}}{1+\pi}=\mu
\end{aligned}
$$




\section{Steady states with portfolio diversification}

Problem :

$\operatorname{Max} U=\ln c_{t}{ }^{h}(t)+\ln c_{t}{ }^{h}(t+1)$

s.t.

$$
c_{t}{ }^{h}(t)+\frac{c_{t}{ }^{h}(t+1)}{d_{t}(t+1)}=\bar{w}_{t}{ }^{h}(t)
$$

$$
\begin{aligned}
& v_{t}{ }^{h}(t+1)=\pi k_{t}{ }^{h}(t+1)\left[r_{t}(t+1)-i_{t}(t+1)\right] \\
& \rho_{t}(t+1) K_{t}(t+1)=\pi i_{t}(t+1) K_{t}(t+1)-d_{t}(t+1) S_{t}(t)
\end{aligned}
$$

The Lagrangian is therefore :

$$
\begin{aligned}
& L=\ln c_{t}{ }^{h}(t)+\ln c_{t}{ }^{h}(t+1)+\lambda_{1}\left[c_{t}{ }^{h}(t)+\frac{c_{t}{ }^{h}(t+1)}{d_{t}(t+1)}-\bar{w}_{t}(t)\right]+\lambda_{2}\left[\pi k_{t}{ }^{h}(t+1)\left(r_{t}(t+1)-i_{t}(t+1)\right)\right] \\
& +\lambda_{3}\left[\pi i_{t}(t+1) K_{t}(t+1)-d_{t}(t+1) S_{t}(t)\right]
\end{aligned}
$$

and the first order conditions are :

$$
\begin{aligned}
& \frac{\partial L}{\partial c_{t}{ }^{h}(t)}=\frac{1}{c_{t}{ }^{h}(t)}+\lambda_{1}=0 \\
& \frac{\partial L}{\partial c_{t}{ }^{h}(t+1)}=\frac{1}{c_{t}{ }^{h}(t+1)}+\frac{\lambda_{1}}{d_{t}(t+1)}=0 \\
& \frac{\partial L}{\partial \lambda_{1}}=\left(c_{t}{ }^{h}(t)-\bar{w}_{t}{ }^{h}(t)\right) d_{t}(t+1)+c_{t}{ }^{h}(t+1)=0 \\
& \frac{\partial L}{\partial \lambda_{2}}=\pi k_{t}{ }^{h}(t+1)\left(r_{t}(t+1)-i_{t}(t+1)\right)=0 \\
& \frac{\partial L}{\partial \lambda_{3}}=\pi i_{t}(t+1) K_{t}(t+1)-d_{t}(t+1) S_{t}(t)=0
\end{aligned}
$$

Combining equations (A9) and (A10) yields :

$$
\frac{c_{t}^{h}(t+1)}{c_{t}{ }^{h}(t)}=d_{t}(t+1)
$$

From (A11) :

$$
\Rightarrow \quad c_{t}{ }^{h}(t+1)=\left[\bar{w}_{t}{ }^{h}(t)-c_{t}{ }^{h}(t)\right] d_{t}(t+1)
$$

Substituting (A15) into (A14) yields :

$$
c_{t}{ }^{h}(t)=\frac{\bar{w}_{t}{ }^{h}(t)}{2}
$$


To obtain savings, one subtracts consumption from income :

$$
\begin{aligned}
s_{t}{ }^{h}(t) & =\bar{w}_{t}{ }^{h}(t)-c_{t}{ }^{h}(t) \\
\Rightarrow \quad s_{t}{ }^{h}(t) & =\bar{w}_{t}{ }^{h}(t)-\frac{\bar{w}_{t}{ }^{h}(t)}{2}=\frac{\bar{w}_{t}{ }^{h}(t)}{2}
\end{aligned}
$$

The lending rate is obtained from (A12) :

$\Rightarrow \quad r_{t}(t+1)=i_{t}(t+1)$

Using $K_{t}(t+1)=S_{t}(t)$, the deposit rate is obtained from (A13) :

$\Rightarrow \quad d_{t}(t+1)=\pi i_{t}(t+1)$

The growth rate of $\underline{k}_{t}$ is obtained with the following equations :

$$
\begin{aligned}
& \bar{w}_{t}{ }^{h}(t)=(1-\alpha) \pi \underline{k}_{t-1}(t) L_{t}{ }^{-\alpha} \\
& s_{t}{ }^{h}(t)=\underline{k}_{t}(t+1) \\
& s_{t}{ }^{h}(t)=\frac{\bar{w}_{t}{ }^{h}(t)}{2}
\end{aligned}
$$

Substituting (A16) into (A18) yields :

$$
S_{t}^{h}(t)=\frac{(1-\alpha) \pi \underline{k}_{t-1}(t) L_{t}^{-\alpha}}{2}
$$

Using (A17) :

$$
\begin{aligned}
\underline{k}_{t}(t+1) & =\frac{(1-\alpha) \pi \underline{k}_{t-1}(t) L_{t}^{-\alpha}}{2} \\
\Rightarrow \quad \frac{\underline{k}_{t}(t+1)}{\underline{k}_{t-1}(t)} & =\frac{(1-\alpha) \pi L_{t}^{-\alpha}}{2}
\end{aligned}
$$




\section{Steady states with portfolio diversification and asset valuation}

Calculation of $\delta^{*}$

$[\delta+(1-\delta) \pi] i_{t}(t+1) K_{t}(t+1)$

return with asset valuation

$\pi i_{t}(t+1) K_{t}(t+1)$

return without asset valuation

$\delta^{2} \kappa$ cost of evaluation

At $\delta^{*}$, the cost of evaluation should be equal to the difference in returns with and without asset valuation i.e. :

$$
\begin{gathered}
\delta^{*^{2}} \kappa=\left[\delta^{*}+\left(1-\delta^{*}\right) \pi\right] i_{t}(t+1) K_{t}(t+1)-\pi i_{t}(t+1) K_{t}(t+1) \\
\Rightarrow \quad \delta^{*}=\frac{(1-\pi) i_{t}(t+1) K_{t}(t+1)}{\kappa}
\end{gathered}
$$

As the economy grows, $K_{t}(t+1)$, the amount of capital lent will grow, pushing $\delta^{*}$ to its upper bound, i.e. 1 . In the steady state, $\delta^{*}$ will thus equal 1 and the problem therefore becomes :

$\operatorname{Max} U=\ln c_{t}^{h}(t)+\ln c_{t}^{h}(t+1)$

s.t.

$$
c_{t}{ }^{h}(t)+\frac{c_{t}{ }^{h}(t+1)}{d_{t}(t+1)}=\bar{w}_{t}{ }^{h}(t)
$$

$$
\begin{aligned}
& v_{t}{ }^{h}(t+1)=k_{t}{ }^{h}(t+1)\left[r_{t}(t+1)-i_{t}(t+1)\right] \\
& \rho_{t}(t+1) K_{t}(t+1)=i_{t}(t+1) K_{t}(t+1)-d_{t}(t+1) S_{t}(t)-\kappa
\end{aligned}
$$

The Lagrangian is therefore :

$$
\begin{aligned}
& L=\ln c_{t}{ }^{h}(t)+\ln c_{t}{ }^{h}(t+1)+\lambda_{1}\left[c_{t}{ }^{h}(t)+\frac{c_{t}{ }^{h}(t+1)}{d_{t}(t+1)}-\bar{w}_{t}(t)\right]+\lambda_{2}\left[k_{t}{ }^{h}(t+1)\left(r_{t}(t+1)-i_{t}(t+1)\right)\right] \\
& +\lambda_{3}\left[i_{t}(t+1) K_{t}(t+1)-d_{t}(t+1) S_{t}(t)-\kappa\right]
\end{aligned}
$$




\section{REFERENCES}

BENCIVENGA, V. and B. SMITH (1991), "Financial intermediation and endogenous growth", Review of Economic Studies, Vol. 58, pp. 195-209.

BERNANKE, B. and M. GERTLER (1989), "Agency costs, net worth, and business fluctuations", American Economic Review, March, pp. 14-31.

CAMERON, R. (1967), Banking in the Early Stages of Industrialization: A Study in Comparative Economic History (New York: Oxford University Press).

van EES, H. and S.J. van den HEUVEL (1994), "Investment, aggregate shocks and imperfect financial markets", SOM Research Report (Groningen, the Netherlands: University of Groningen), October.

FAMA, E.F. (1985), "What's different about banks?", Journal of Monetary Economics, Vol. 15, January, pp. 29-39.

GOLDSMITH, R.W. (1969), Financial Structure and Development (New Haven, CT: Yale University Press).

GREENWOOD, J. and B. JOVANOVIC (1990), "Financial development, growth and the distribution of income", Journal of Political Economy, Vol. 98, pp. 1076-1107.

JAYARATNE, J. and P.E. STRAHAN (1996), "The finance-growth nexus: Evidence from bank branch deregulation", Quarterly Journal of Economics, Vol. 111, August, pp. 639-670.

KING, R. and R. LEVINE (1993a), "Finance, entrepreneurship and growth", Journal of Monetary Economics, Vol. 32, pp. 513-542.

KING, R. and R. LEVINE (1993b), "Finance and growth: Schumpeter might be right", Quarterly Journal of Economics, August, pp. 717-737.

McKINNON, R.I. (1973), Money and Capital in Economic Development (Washington, DC: Brookings Institution).

LEVINE, R. (1991), "Stock markets, growth and tax policy", Journal of Finance, Vol. 46, September, pp. $1445-1465$. 
PAGANO, M. (1993), "Financial markets and growth: An overview", European Economic Review, Vol. 37, pp. 613-622.

ROMER, P. (1986), "Increasing returns and long-run growth", Journal of Political Economy, Vol. 94, pp. 1002-1037.

SAINT-PAUL, G. (1992), "Technological choice, financial markets and economic development", European Economic Review, Vol. 36, pp. 763-781.

SHAW, E.S. (1973), Financial Deepening in Economic Development (New York: Oxford University Press). 


\section{UNCTAD Discussion Papers}

No. 38, April 1991

No. 39, April 1991

No. 40, August 1991 Issues

No. 41, August 1991

No. 42, October 1991 industry

*No. 43, February 1992

*No. 44, July 1992

No. 45, July 1992

No. 46, July 1992

No. 47, August 1992

No. 48, August 1992

No. 49, October 1992

No. 50, November 1992 and its

No. 51, December 1992

No. 52, December 1992

No. 53, December 1992
J. F. OUTREVILLE

Andrew J. CORNFORD

Yilmaz AKYÜZ \&

Detlef J. KOTTE

Manuel R. AGOSIN

Georg KELL \&

Jürgen RICHTERING

Yilmaz AKYÜZ

Cem SOMEL

Sebastian SCHICH

Raju J. SINGH

V. BHASKAR

Ha-Joon CHANG \& Ajit SINGH

Ajit SINGH

Ulrich HOFFMANN \&

Dusan ZIVKOVIC

Sebastian SCHICH

Dwight H. PERKINS

Patricio MELLER
The use of computer technology in the insurance sector of developing countries

The Multilateral Negotiations on Banking Services: Context and selected outstanding issues

Financial policies in developing countries: and experience

Trade policy reform and economic performance: A review of the issues and some preliminary evidence

Technology and competitiveness in the textile

On financial deepening and efficiency

Finance for growth: Lessons from Japan

Indebtedness, sovereign risk and the spread: The example of Hungary and the Euromarkets An imperfect information approach to the structure of the financial system

Privatization and the developing countries: The issues and the evidence

Public enterprises in developing countries and economic efficiency

The stock-market and economic development: Should developing countries encourage stock-markets?

Demand growth for industrial raw materials determinants: An analysis for the period 1965-1988

Indebtedness, creditworthiness and trade finance and payment arrangements

China's 'gradual' approach to market reforms

Latin American adjustment and economic reforms: Issues and recent experience

* Out of stock. 
No. 54, January 1993

No. 55, February 1993

No. 56, March 1993

No. 57, April 1993

No. 58, April 1993

No. 59, May 1993

No. 60, July 1993

No. 61, July 1993

No. 62, July 1993

No 63, July 1993

savings: A

No. 64, July 1993

savings: A

No. 65, August 1993

No. 66, August 1993

No. 67, September 1993

No. 68, September 1993

No. 69, September 1993

No. 70, October 1993

No. 71, October 1993

policy
Trevor GARDNER

Alexandre R. BARROS

Yilmaz AKYÜZ

Alice H. AMSDEN

Celso ALMEIDA

Ali-Reza NIKPAY

Jean-Marc FONTAINE

Korkut BORATAV

Roberto FRENKEL

Machiko NISSANKE \&

Priya BASU

Machiko NISSANKE \&

Priya BASU

Ercan UYGUR

Y_lmaz AKYÜZ

Cem SOMEL

Andrew CORNFORD

Sebastian SCHICH

Veena JHA, René VOSSENAAR \& Simonetta ZARRILLI

Adolfo CANITROT
The present economic situation in Zambia and the role of privatisation in improving its economy

Prospects for world sugar trade

Financial liberalization: The key issues

Structural macroeconomic underpinnings of effective industrial policy: Fast growth in the 1980s in five Asian countries

Development and transfer of environmentally sound technologies in manufacturing: A survey

Privatization in Eastern Europe: A survey of the main issues

Reforming public enterprises and the public sector in sub-Saharan Africa

Public sector, public intervention and economic development

Growth and structural reform in Latin America: Where we stand

Mobilization and allocation of domestic study on Bhutan

Mobilization and allocation of domestic case study on Nepal

Liberalization and economic performance in Turkey

Maastricht and fiscal retrenchment in Europe

The State in economic activity: Problems of economic policy-making

The role of the Basle Committee on Banking Super- vision in the regulation of international banking

The level and volatility of external financial positions and the costs of export credit insurance

Ecolabelling and international trade

The exchange rate as an instrument of trade 
No. 72, October 1993

No. 73, November 1993

No. 74, November 1993

No. 75, November 1993

No. 76, December 1993

No. 77, January 1994

No. 78, January 1994

No. 79, February 1994 regional

No. 80, February 1994

No. 81, March 1994

No. 82: WITHDRAWN

No. 83, May 1994

and some

No. 84, May 1994

No. 85, July 1994

No. 86, July 1994

No. 87, July 1994

No. 88, August 1994

No. 89, September 1994
Xiaoning J. ZHAN

J.H. REICHMAN

Priya BASU \& Norman GEMMELL

William W.F. CHOA

Ajit SINGH

Shigehisa KASAHARA

Jean K. THISEN

Kálmán KALOTAY \&

Ana María ALVAREZ

Edouard DOMMEN

Juan A. DE CASTRO

Y_lmaz AKYÜZ \&

Andrew CORNFORD

David FELIX

S.M. SHAFAEDDIN

Raju J. SINGH

Thomas ZIESEMER

Sebastian SCHICH

Veena JHA \&
North American economic integration and its impli- cations for the exports of China and Hong Kong

Implications of the Draft TRIPS Agreement for developing countries as competitors in an integrated world market

Fiscal adjustment in the Gambia: A case study

The relevance of market structure to technological progress: A case study of the chemical industry

The Plan, the market and evolutionary economic reform in China

A rescue plan for the post-bubble Japanese economy: The establishment of the Cooperative Credit Purchasing Company

The European Single Market and its possible effects on African external trade

Emerging stock markets and the scope for cooperation

Développement durable: Mots-déclic

The internalization of external environmental costs and sustainable development

Regimes for international capital movements proposals for reform

Industrial development in East Asia: What are the lessons for Latin America?

The impact of trade liberalization on export and GDP growth in least developed countries

Bank credit, small firms and the design of a financial system for Eastern Europe

Economic development and endogenous terms-of-trade determination: Review and reinterpretation of the Presbisch-Singer Thesis The payment arrangements in the trade of CEECs and LDCs between 1986 and 1994 Are environmentally sound technologies the 
No. 90, October 1994

No. 91, October 1994

No. 92, November 1994

No. 93, December 1994

No. 94, January 1995

No. 95, January 1995

No. 96, February 1995

No. 97, February 1995

No. 98, April 1995

No. 99, May 1995

No. 100, August 1995

No. 101, August 1995

democracy and

No. 102, August 1995

No. 103, September 1995 export

No. 104, September 1995

No. 105, October 1995

No. 106, October 1995

No. 107, November 1995

No. 108, November 1995

No. 109, December 1995
Ana Paola TEIXEIRA

Manuel R. AGOSIN

Y_lmaz AKYÜZ \&

Charles GORE

Charles GORE

J. F. OUTREVILLE

XIE Ping

William W.F. CHOA

Alexandre R. BARROS

Ajit SINGH

Z. KOZUL-WRIGHT

Juan A. DE CASTRO

Roberto FRENKEL

R. KOZUL-WRIGHT

\& Paul RAYMENT

J.C. DE SOUZA BRAGA Financing the public sector in Latin America M.A. MACEDO CINTRA

\& Sulamis DAIN

Toni HANIOTIS \&

Sebastian SCHICH

Robert ROWTHORN

Giovanni N. DE VITO

John EATWELL

Luisa E. SABATER

David FELIX

Urvashi ZUTSHI
Emperor's new clothes?

Saving and investment in Latin America

The investment-profits nexus in East Asian industrialization

Development strategy in East Asian newly industrializing economies: The experience of post-war Japan, 1953-1973

Life insurance in developing countries: A cross-country analysis

Financial services in China

The derivation of trade matrices by commodity groups in current and constant prices

The role of wage stickiness in economic growth How did East Asia grow so fast? Slow progress towards an analytical consensus

The role of the firm in the innovation process

Trade and labour standards: Using the wrong instruments for the right cause

Macroeconomic sustainability and development prospects: Latin American performance in the 1990s

Walking on two legs: Strengthening productive entrepreneurship in the transition economies

Should governments subsidize exports through credit insurance agencies?

A simulation model of North-South trade

Market distortions and competition: the particular case of Malaysia

Disguised unemployment: The G7 experience Multilateral debt of least developed countries Financial globalization versus free trade: The case for the Tobin tax

Aspects of the final outcome of the negotiations on financial services of the Uruguay Round 
No. 110, January 1996

No. 111, January 1996

No. 112, March 1996

No. 113, March 1996 reflections on

No. 114, April 1996

No. 115, April 1996

No. 116, June 1996

No. 117, August 1996

No. 118, September 1996

No. 119, September 1996

No. 120, October 1996

No. 121, October 1996

No. 122, December 1996

No. 123, December 1996 special

No. 123, December 1996 special

No. 124, March 1997
H.A.C. PRASAD

Charles GORE

Djidiack FAYE

Paul BAIROCH \&

Richard KOZUL-WRIGHT

Rameshwar TANDON

E.V.K. FITZGERALD

Jussi LANKOSKI

José RIPOLL

Sunanda SEN

Leena ALANEN

Sinan AL-SHABIBI

J.F. OUTREVILLE

Jörg MAYER

L. RUTTEN \&

L. SANTANA-BOADO

L. RUTTEN \&

L. SANTANA-BOADO Jörg MAYER growth in the world economy

Bilateral terms of trade of selected countries from the South with the North and the South Methodological nationalism and the misunderstanding of East Asian industrialization

Aide publique au développement et dette extérieure: Quelles mesures opportunes pour le financement du secteur privé en Afrique?

Globalization myths: Some historical Japanese financial deregulation since 1984 Intervention versus regulation: The role of the IMF in crisis prevention and management Controlling agricultural nonpoint source pollution: The case of mineral balances Domestic insurance markets in developing countries: Is there any life after GATS?

Growth centres in South East Asia in the era of globalization

The impact of environmental cost internalization on sectoral competitiveness: A new conceptual framework

Structural adjustment for the transition to disarmament: An assessment of the role of the market

Reinsurance in developing countries: Market structure and comparative advantage

Implications of new trade and endogenous growth theories for diversification policies of commodity-dependent countries

Collateralized commodity financing, with reference to the use of warehouse receipts Collateralized commodity financing with reference to the use of warehouse receipts Is having a rich natural-resource endowment detrimental to export diversification? 
No. 125, April 1997

No. 126, April 1997
Brigitte BOCOUM

Jussi LANKOSKI
The new mining legislation of Côte d'Ivoire: Some comparative features

Environmental effects of agricultural trade liberalization and domestic agricultural policy reforms

Copies of UNCTAD Discussion Papers and Reprint Series may be obtained from the Editorial Assistant, UNCTAD, Palais des Nations, CH-1211 Geneva 10, Switzerland (Tel. 41-22-907.5733, Fax 41-22-907.0043/0057). 